Potential Containment Materials for

Liquid-Lead and Lead-Bismuth Eutectic

Spallation Neutron Source

John J. Park

Darryl P. Butt

Carl A. Beard

DISTRLUTION OF THIS DOCUMENT IS UNIMIED ph

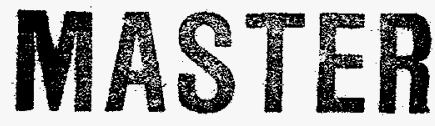




\section{DISCLAIMER}

This report was prepared as an account of work sponsored by an agency of the United States Government. Neither the United States Government nor any agency thereof, nor any of their employees, make any warranty, express or implied, or assumes any legal liability or responsibility for the accuracy, completeness, or usefulness of any information, apparatus, product, or process disclosed, or represents that its use would not infringe privately owned rights. Reference herein to any specific commercial product, process, or service by trade name, trademark, manufacturer, or otherwise does not necessarily constitute or imply its endorsement, recommendation, or favoring by the United States Government or any agency thereof. The views and opinions of authors expressed herein do not necessar. ily state or reflect those of the United States Government or any agency thereof. 


\section{DISCLAIMER}

Portions of this document may be illegible electronic image products. Images are produced from the best available original document. 


\section{Contents}

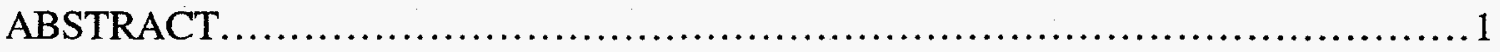

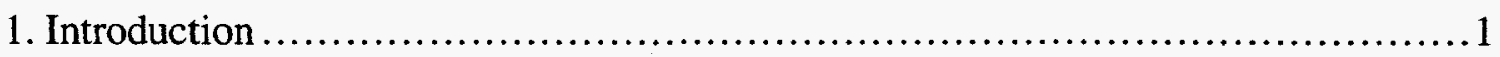

2. Lead Target.......................................................................

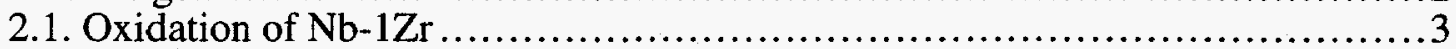

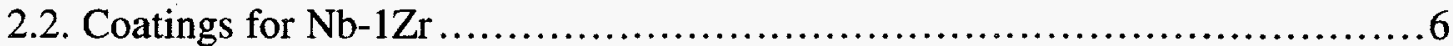

2.3. $\mathrm{Nb}-1 \mathrm{Zr}$ Proton Irradiation Experiments at LANL $\ldots \ldots \ldots \ldots \ldots \ldots \ldots \ldots \ldots \ldots \ldots \ldots$

2.4. Molybdenum, Tantalum, and Tungsten .................................... 9

3. Lead-Bismuth Eutectic Target................................................. 9

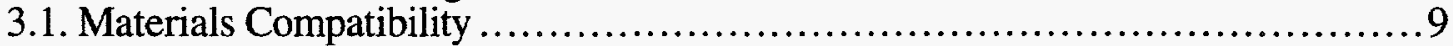

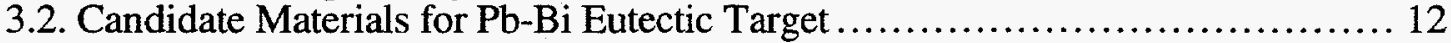

3.2.1. 2-1/4Cr-1Mo Steel ................................................... 13

3.2.2. Modified 9Cr-1Mo Steel.......................................... 13

3.2.3. 12Cr-1Mo Steel............................................ 13

4. Other Low-Melting-Point Alloys ........................................... 14

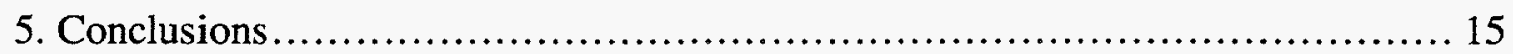

6. Acknowledgments...................................................... 15

7. References................................................................ 16 


\section{List of Tables}

Table 1. Advantages and disadvantages of $\mathrm{Pb}$ and $\mathrm{Pb}-\mathrm{Bi}$ eutectic targets. ...............2

Table 2. Minimum $\mathrm{Nb}-1 \mathrm{Zr}$ wall thickness required at each condition for

l-year operation at $900^{\circ} \mathrm{C}$.

Table 3 . Results of lead-bismuth eutectic thermal convection loop test [13].

Table: 4. Corrosion of steels in lead-bismuth eutectic [16]

Table 5. Solubilities of several metals in lead-bismuth eutectic $[12,13] \ldots$

Table 6. Corrosion of Croloy 2-1/4 in lead-magnesium eutectic [25]....

14

Table 7 . Alloys with melting points below $100^{\circ} \mathrm{C}$

14

\section{List of Figures}

Figure 1 . Weight gain of $\mathrm{Nb}-1 \mathrm{Zr}$ in pure oxygen at a heating rate of $2^{\circ} \mathrm{C} / \mathrm{min} \ldots \ldots \ldots \ldots . .4$

Figure 2. Weight changes of uncoated plasma-sprayed $\mathrm{MoSi}_{2}$-coated $\mathrm{Nb}-1 \mathrm{Zr}$ at $900^{\circ} \mathrm{C}$ in pure oxygen.

Figure 3. Irradiation assembly.

.8 


\title{
Potential Containment Materials for Liquid-Lead and Lead-Bismuth Eutectic Spallation Neutron Source
}

\author{
by
}

John J. Park, Darryl P. Butt, and Carl A. Beard

\begin{abstract}
Lead $(\mathrm{Pb})$ and lead-bismuth eutectic $(44 \mathrm{~Pb}-56 \mathrm{Bi})$ have been the two primary candidate liquid-metal target materials for the production of spallation neutrons. Selection of a container material for the liquid-metal target will greatly affect the lifetime and safety of the target subsystem. For the lead target, niobium-1 (wt\%) zirconium ( $\mathrm{Nb}-1 \mathrm{Zr}$ ) is a candidate containment material for liquid lead, but its poor oxidation resistance has been a major concern. The oxidation rate of $\mathrm{Nb}-1 \mathrm{Zr}$ was studied based on the calculations of thickness loss due to oxidation. According to these calculations, it appeared that uncoated $\mathrm{Nb}-1 \mathrm{Zr}$ may be used for a one-year operation at $900^{\circ} \mathrm{C}$ at $\mathrm{P}_{\mathrm{O}_{2}}=1 \times 10^{-6}$ torr, but the same material may not be used in argon with 5-ppm oxygen. Coating technologies to reduce the oxidation of $\mathrm{Nb}-1 \mathrm{Zr}$ are reviewed, as are other candidate refractory metals such as molybdenum, tantalum, and tungsten. For the $\mathrm{Pb}-\mathrm{Bi}$ target, three candidate containment materials are suggested based on a literature survey of the materials compatibility and proton irradiation tests: Croloy $2-1 / 4$, modified $9 \mathrm{Cr}-1 \mathrm{Mo}$, and $12 \mathrm{Cr}-1 \mathrm{Mo}$ (HT-9) steel. These materials seem to be used only if the lead-bismuth is thoroughly deoxidized and treated with zirconium and magnesium.
\end{abstract}

\section{Introduction}

In the current preconceptual design for the Los Alamos National Laboratory (LANL) Accelerator Based Conversion of Plutonium/Accelerator Transmutation of Waste (ABC/ATW), flowing liquid metal is the primary candidate target for use as a compact, high-power spallation neutron source. As $800-\mathrm{MeV}$ protons generated from an accelerator impinge on the liquid metal target, neutrons are generated by a spallation process. These neutrons then are used to burn plutonium or to transmute high-level wastes. The advantages of a liquid-metal target for these applications are fast cooling of the target by flowing-liquid-metal coolant, great power density, and no irradiation damage to the target material. Lead $(\mathrm{Pb})$ and lead-bismuth eutectic (44Pb-56Bi) have been the two leading candidate target materials for the production of spallation neutrons because of their high atomic numbers, low melting points, and low parasitic neutron capture. As shown in Table 1, lead has the advantages of less polonium ( $\mathrm{Po}$ ) production and less corrosiveness. However, due to its higher melting point $\left(327^{\circ} \mathrm{C}\right)$ than $\mathrm{Pb}-\mathrm{Bi}$ eutectic $\left(125^{\circ} \mathrm{C}\right), \mathrm{Pb}$ would require higher operating temperatures. 
Table 1. Advantages and disadvantages of $\mathrm{Pb}$ and $\mathrm{Pb}-\mathrm{Bi}$ eutectic targets.

\begin{tabular}{||l|l|l|}
\hline \hline $\mathrm{Pb}$ & Advantages & Disadvantages \\
\hline $\mathrm{Pb}-\mathrm{Bi}$ eutectic & $\begin{array}{l}\text { Less Po production } \\
\text { Less corrosive } \\
\left.\text { (m.p. }=125^{\circ} \mathrm{C}\right)\end{array}$ & $\begin{array}{l}\text { Higher operating temperature } \\
\left(\mathrm{m} . \mathrm{p} .=327^{\circ} \mathrm{C}\right)\end{array}$ \\
\hline
\end{tabular}

Because the beam window is an integral part of the target containment structure, the structural container for the liquid metal will be exposed to a significant flux of high-energy protons and neutrons as well as an extremely corrosive environment. Selection of the container material for the flow passage will greatly affect the lifetime and safety of the target subsystem. The material should have good compatibility with the liquid-metal target, sufficient mechanical strength at operating temperatures, a low-neutron-absorption cross section, and good performance under an intense proton environment. In this paper, we discuss the potential containment materials for the $\mathrm{Pb}$ and $\mathrm{Pb}-\mathrm{Bi}$ eutectic target that were investigated based on the above criteria.

\section{Lead Target}

In the LANL ABC/ATW preconceptual liquid-lead target design, it is estimated that the maximum temperature of the system will be approximately $900^{\circ} \mathrm{C}$ at the point where the proton beam impinges on the window. In this temperature range, iron-base alloys are inadequate because of their high creep rates and poor oxidation resistance. Iron-base alloys are usually limited to up to $650-700^{\circ} \mathrm{C}$ service temperatures. Similarly, nickel-base and cobalt-base superalloys are only marginally acceptable because they are limited to up to $900-1000^{\circ} \mathrm{C}$. Another consideration for the use of these superalloys is that nickel is incompatible with liquid lead, and cobalt has a very-high-absorption cross section. Refractory metals such as niobium ( $\mathrm{Nb}$ ), tantalum (Ta), molybdenum (Mo), and tungsten (W) are usually used at service temperatures well above $900^{\circ} \mathrm{C}$.

It is anticipated that, for the LANL $\mathrm{ABC} / \mathrm{ATW}$ system, temperature-gradient mass transfer will be the most damaging type of all materials degradation phenomena in liquid metal because of large temperature gradient in the system. The solubility of the container material in the liquid metal is a function of temperature. After a period of operation, solubility limits are reached, and the temperature-dependent solubility results in the transfer of the container material from the hottest location to the coldest location in the flowing loop. The effect in the circulating molten lead target is to dissolve container material from the 
window and deposit it in the heat exchanger. Both the thinning of the window and potential fouling of the heat exchanger are undesirable.

The relative resistance to mass transfer of 24 metals and alloys in liquid lead with a temperature gradient of $300^{\circ} \mathrm{C}\left(800-500^{\circ} \mathrm{C}\right)$ was measured by Cathcart and Manly [1]. The results indicated that only $\mathrm{Nb}$ and Mo showed no mass transfer, while the other materials showed little to heavy mass transfer. Other parameters to consider in the selection of candidate materials are good mechanical properties in intense irradiation environments and low-neutron-absorption cross sections. Based on the mass-transfer behavior, proton irradiation behavior, mechanical strength at operating temperatures, and neutron-absorption cross section of candidate materials, $\mathrm{Nb}-1 \mathrm{Zr}$ has been selected as a containment material for the ABC/ATW liquid-lead target [2].

\subsection{Oxidation of $\mathrm{Nb}-1 \mathrm{Zr}$}

Although $\mathrm{Nb}-1 \mathrm{Zr}$ has desirable properties for the liquid- $\mathrm{Pb}$ target, one major drawback is its low oxidation resistance at high temperatures. Thus, the ABC/ATW lead target is designed to be used in vacuum or at very low oxygen partial pressures.

Some preliminary oxidation experiments of $\mathrm{Nb}-1 \mathrm{Zr}$ were performed at LANL. Figure 1 shows the weight gain of $\mathrm{Nb}-1 \mathrm{Zr}$ in pure oxygen at a heating rate of $2^{\circ} \mathrm{C} / \mathrm{min}$. From nonisothermal thermogravimetric analysis, the oxidation rate was determined to be $62.2 \mathrm{mg} / \mathrm{cm}^{2} \cdot \mathrm{h}$ in the temperature range of $700-800^{\circ} \mathrm{C}$. The oxidation rate of $\mathrm{Nb}-1 \mathrm{Zr}$ in argon with 5-ppm oxygen at $900^{\circ} \mathrm{C}$ for $20 \mathrm{hr}$ was $7.2 \mathrm{mg} / \mathrm{cm}^{2}\left(0.36 \mathrm{mg} / \mathrm{cm}^{2} \cdot \mathrm{h}\right)$. Oxide scales were formed on the surface of the sample. Figure 2 shows the weight changes of uncoated and plasma-sprayed $\mathrm{MoSi}_{2}$-coated $\mathrm{Nb}-1 \mathrm{Zr}$ at $900^{\circ} \mathrm{C}$ in pure oxygen. The experiment was terminated when the specimen broke loose from the platinum (Pt) hangdown wire. As expected, the oxidation kinetics under these conditions were extremely rapid. Based on the rapid oxidation rates and appearance of the sample after oxidation, the oxidation was thought to be autocatalytic. Although perfectly intact at the end of the experiment, the $\mathrm{MoSi}_{2}$ coating provided no significant protection from oxidation. This was attributed to lack of time to develop the coating techniques. 


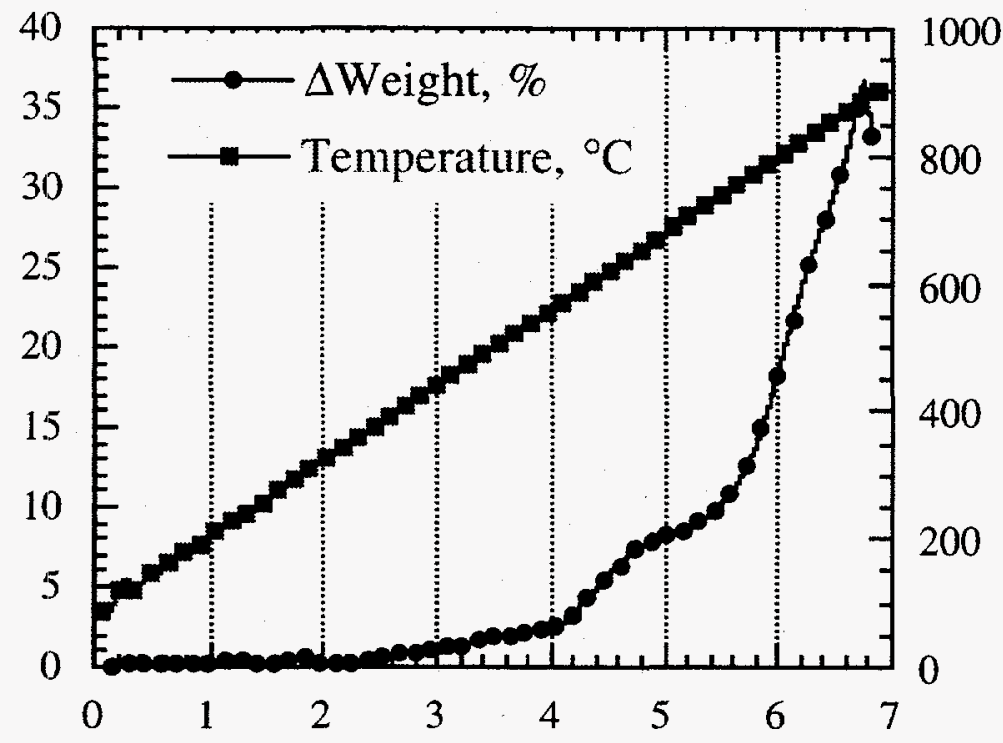

Figure 1. Weight gain of $\mathrm{Nb}-1 \mathrm{Zr}$ in pure oxygen at a heating rate of $2^{\circ} \mathrm{C} / \mathrm{min}$.

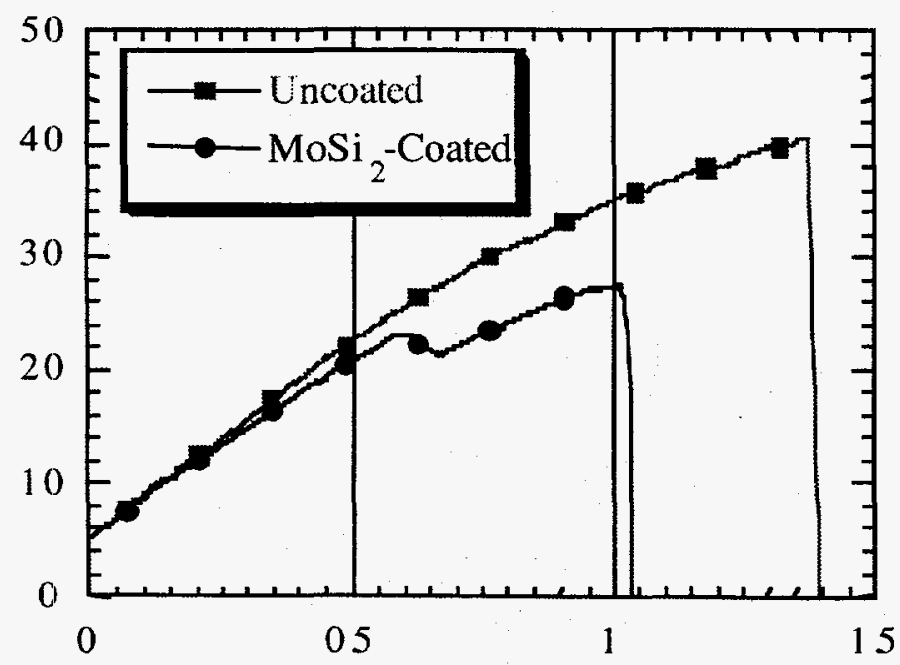

Figure 2. Weight changes of uncoated and plasma-sprayed $\mathrm{MoSi}_{2}$-coated $\mathrm{Nb}-1 \mathrm{Zr}$ at $900^{\circ} \mathrm{C}$ in pure oxygen.

The oxidation behavior of $\mathrm{Nb}-1 \mathrm{Zr}$ has been studied by many investigators. DiStefano and Hendricks [3] measured the oxidation rate of $\mathrm{Nb}-1 \mathrm{Zr}$ in vacuum at oxygen partial pressures of $10^{-6}$ and $10^{-7}$ torr at temperatures up to $1077^{\circ} \mathrm{C}$ for $100-150 \mathrm{hr}$. Under these conditions, no visible oxide films formed. The oxidation rate at $\mathrm{P}_{\mathrm{O}_{2}}=1 \times 10^{-6}$ torr and $900^{\circ} \mathrm{C}$ was expressed as $\mathrm{r}=6 \times 10^{-3} \mathrm{mg} / \mathrm{cm}^{2} \cdot \mathrm{h}$. At $\mathrm{P}_{\mathrm{O}_{2}}=1 \times 10^{-7}$ torr and $900^{\circ} \mathrm{C}$, the oxidation rate was expressed as $\mathrm{r}=3.4 \times 10^{-4} \mathrm{mg} / \mathrm{cm}^{2} \cdot \mathrm{h}$. Delgrosso [4] measured the oxidation rate of $\mathrm{Nb}-1 \mathrm{Zr}$ in air at $871^{\circ} \mathrm{C}$, and it was $36 \mathrm{mg} / \mathrm{cm}^{2} \cdot \mathrm{h}$. 
Niobium pentoxide $\left(\mathrm{Nb}_{2} \mathrm{O}_{5}\right)$ is the end product of the oxidation. It is a white solid with densities that may vary between $4.3-5.2 \mathrm{~g} / \mathrm{cm}^{3}$ depending on the method of preparation and subsequent heat treatment [5]. The oxidation rate of $\mathrm{Nb}-1 \mathrm{Zr}$ can be converted to thickness loss due to oxidation. Assuming all the oxide is $\mathrm{Nb}_{2} \mathrm{O}_{5}$, the oxidation rate in argon with 5ppm oxygen at $900^{\circ} \mathrm{C}$ measured by LANL $\left(0.36 \mathrm{mg} / \mathrm{cm}^{2} \cdot \mathrm{h}\right)$ equals $2.5 \mu \mathrm{m} / \mathrm{h}$. The thickness loss during a one-year operation in argon with 5-ppm oxygen would be $2.19 \mathrm{~cm}$. Also, the oxidation rate measured by DiStefano and Hendricks [3] at $\mathrm{P}_{\mathrm{O}_{2}}=1 \times 10^{-6}$ torr and $900^{\circ} \mathrm{C}$ equals $0.0417 \mu \mathrm{m} / \mathrm{h}$. Thus, the thickness loss during a one-year operation at $\mathrm{P}_{\mathrm{O}_{2}}=1 \times 10^{-6}$ torr and $900^{\circ} \mathrm{C}$ would be $0.0365 \mathrm{~cm}$. Using the same reasoning, the thickness loss at $\mathrm{P}_{\mathrm{O}_{2}}=1 \times 10^{-7}$ torr and $900^{\circ} \mathrm{C}$ measured by DiStefano and Hendricks [3] equals $0.00207 \mathrm{~cm}$.

If we assume that a loss of $20 \%$ of the wall thickness is acceptable during one year of operation, the required minimum wall thickness of $\mathrm{Nb}-1 \mathrm{Zr}$ that is exposed in argon with 5 -ppm oxygen would be $10.95 \mathrm{~cm}$. Under the same assumption, the required minimum wall thickness of $\mathrm{Nb}-1 \mathrm{Zr}$ exposed to $\mathrm{P}_{\mathrm{O}_{2}}=1 \times 10^{-6}$ torr at $900^{\circ} \mathrm{C}$ and to $\mathrm{P}_{\mathrm{O}_{2}}=1 \times 10^{-7}$ torr at $900^{\circ} \mathrm{C}$ would be 0.183 and $0.01 \mathrm{~cm}$, respectively.

Calculations also were made based on an assumption that loss of $10 \%$ of wall thickness is acceptable. Table 2 shows the required minimum $\mathrm{Nb}-1 \mathrm{Zr}$ wall thickness at each condition for one-year operation at $900^{\circ} \mathrm{C}$ under the $10 \%$ and $20 \%$ thickness loss criteria.

Table 2. Minimum $\mathrm{Nb}-1 \mathrm{Zr}$ wall thickness required at each condition for 1-year operation at $900^{\circ} \mathrm{C}$.

\begin{tabular}{||l|l|l|l|}
\hline Environment & $\begin{array}{l}\text { Thickness } \\
\text { loss }(\mathrm{cm})\end{array}$ & $\begin{array}{l}\text { Minimum wall thickness } \\
\text { permitting 20\% loss }(\mathrm{cm})\end{array}$ & $\begin{array}{l}\text { Minimum wall thickness } \\
\text { permitting 10\% loss }(\mathrm{cm})\end{array}$ \\
\hline Argon $\left(5 \mathrm{ppm} \mathrm{O}_{2}\right)$ & 2.19 & 10.95 & 21.9 \\
\hline $\mathrm{P}_{\mathrm{O} 2}=1 \times 10^{-6}$ torr & 0.0365 & 0.183 & 0.3650 \\
\hline $\mathrm{P}_{\mathrm{O} 2}=1 \times 10^{-7}$ torr & 0.00207 & 0.01 & 0.02 \\
\hline
\end{tabular}

The table suggests that the ABC/ATW target system may not employ uncoated $\mathrm{Nb}-1 \mathrm{Zr}$ in argon with a 5-ppm oxygen environment because it requires a minimum wall thickness of $10.95 \mathrm{~cm}$ using the $20 \%$ thickness loss criterion. Uncoated $\mathrm{Nb}-1 \mathrm{Zr}$ may be used for oneyear operation at $900^{\circ} \mathrm{C}$ at $\mathrm{P}_{\mathrm{O}_{2}}=1 \times 10^{-6}$ torr with a minimum wall thickness of $0.183 \mathrm{~cm}$ and the $20 \%$ thickness loss criterion. At $\mathrm{P}_{\mathrm{O}_{2}}=1 \times 10^{-7}$ torr and $900^{\circ} \mathrm{C}$, the thickness loss of $\mathrm{Nb}-1 \mathrm{Zr}$ after a year of operation is only $0.002 \mathrm{~cm}$; thus, uncoated $\mathrm{Nb}-1 \mathrm{Zr}$ may be used for one year. These calculations are based on the assumption that all the oxidation phenomena results in the thickness loss from the surface of the material. However, the 
internal-oxidation effects on both the mechanical properties of $\mathrm{Nb}-1 \mathrm{Zr}$ and corrosion resistance to liquid metals may be significant [6]. Further study is required.

During the operation of the ABC system, spallation products such as hydrogen and oxygen will build up through the interaction of high-energy protons with the target material. These products will behave as alloying or impure elements in the liquid-lead or lead-bismuth target material where they are formed, and thus will have beneficial, neutral, or detrimental effects on the containment material. Initial calculations showed that less than $1 \times 10^{-15}$ atoms/proton of oxygen will be produced [7]. This amount seems to be negligible; however, more detailed study on oxygen production rate and on the interaction between the oxygen and other spallation products is required. Hydrogen embrittlement is another consideration. Stephens [8] conducted a hydrogen embrittlement experiment of $\mathrm{Nb}$ $1 \mathrm{Zr}$ by doping $10 \mathrm{ppm}$ of hydrogen at $1040^{\circ} \mathrm{C}$ in a partial pressure of hydrogen of approximately $13 \mathrm{KN} / \mathrm{m}^{2}$ for $10 \mathrm{~min}$. Based on his experiment, he concluded that $\mathrm{Nb}-1 \mathrm{Zr}$ was not susceptible to hydrogen embrittlement at SP-100 operating conditions because of the small amount of hydrogen that would be encountered. For ABC/ATW systems, initial calculations showed that hydrogen is expected to be produced at a rate of 3.265 atoms/proton [7], which seems to be a significant amount. A further study on the hydrogen production rates and hydrogen embrittlement is required.

\subsection{Coatings for $\mathrm{Nb}-1 \mathrm{Zr}$}

A literature survey revealed that many coating technologies for niobium alloys have been developed. These coating techniques can be used to protect the $\mathrm{Nb}-1 \mathrm{Zr}$ component for longer service life.

Perkins and Meier [9] reviewed the status of recent technologies to protect niobium from oxidation. Silicide coating were considered to be the best available materials for the oxidation protection of niobium base alloys. Niobium silicides modified with silicides of chromium and iron (R512E) and chromium and titanium (R512A) have been used since the mid-1960s for this purpose. R512E-fusion-coated C103-Nb nozzle flaps have been used for over 15 years on the Pratt \& Whitney F100 jet engine without significant failures. These components are exposed to air and products of combustion at temperatures up to $1427^{\circ} \mathrm{C}$ for hundreds of cycles. Similarly, orbital maneuvering engines for spacecraft, including the space shuttle and satellites, are made of niobium-based alloys coated with R512A or R512E. A major problem with this coating is the mismatch in thermal expansion coefficient, which places the brittle coating in tension on cooling from high temperature. The coating has a ductile to brittle transition temperature in the range of $982-1,093^{\circ} \mathrm{C}$. The 
mismatch in thermal expansion coefficient can form cracks in the surface during cooling. These cracks will normally heal by diffusion when reheated; however, after a number of cycles the cracks can become oxidized and fail to heal on reheating.

Mueller, Wang, and Rapp [10] developed multicomponent silicide coatings of (Mo, $\mathrm{W})(\mathrm{Si}, \mathrm{Ge})_{2}$ to protect niobium-based alloys from high-temperature oxidation. A solid solution of molybdenum and tungsten disilicide doped with germanium constituted a primary coating layer that supported a slow-growing protective $\mathrm{SiO}_{2}$ scale when exposed to high-temperature oxidation. Germanium was added to the cyclic oxidation resistance by increasing the thermal expansion coefficient of the silica film, and tungsten was added to strengthen $\mathrm{MoSi}_{2}$ at high temperatures. The presence of germanium also avoided accelerated low-temperature oxidation by providing better sealant coverage at low temperatures. Coated niobium coupons at $925,1,370$, and $1,540^{\circ} \mathrm{C}$ in air successfully passed 200 cyclic oxidation tests of 1 hour each at $1,370^{\circ} \mathrm{C}$ and 60 cycles of 1 hour each at $1,540^{\circ} \mathrm{C}$.

Packer [11] reviewed silicide coating technologies for refractory metals. In this technique, powders of silicon and coating alloying additions such as chromium, iron, titanium, and hafnium are mixed with an organic lacquer vehicle. Typically the powders are mixed in ratios of $60 \mathrm{wt} \%$ to $90 \mathrm{wt} \%$ silicon with one or more alloying agents. The resultant lacquer/metal powder slurry is handled much like a paint, with concerns over antisettling agents, viscosity control, and drying characteristics. The slurry is applied to a part by painting, spraying, or dipping. Some complex shapes are filled and then drained at a controlled rate. After application of the green, unfired slurry, parts are heat-treated in vacuum at $1,300-1,400^{\circ} \mathrm{C}$. During this heat treatment, the powders react with one another as well as with the substrate, form eutectics, fuse, continue to react with the substrate to form high-melting-point metal silicides, and resolidify isothermally. After resolidification, heat treatment is continued for 30 minutes to one hour to permit interdiffusion between the coating and the substrate and the growth of intermediate silicides at the coating/substrate interface.

DiStefano and Hendricks [3] applied a molybdenum coating to $\mathrm{Nb}-1 \mathrm{Zr}$ and investigated the oxidation rate of molybdenum-coated $\mathrm{Nb}-1 \mathrm{Zr}$. The thin layer $(4 \mu \mathrm{m})$ of molybdenum coating was excellent in preventing oxidation at $500^{\circ} \mathrm{C}$. Metallographic examination of the coated sample after oxidation showed that the molybdenum layer was intact and continuous. However, in a long-term test at $1,077^{\circ} \mathrm{C}$ and $\mathrm{P}_{\mathrm{O}_{2}}=1 \times 10^{-7}$ torr, significant oxygen pickup by a coated sample was found $(806 \mathrm{ppm})$. 


\section{3 $\mathrm{Nb}-1 \mathrm{Zr}$ Proton Irradiation Experiments at LANL}

During the summer of 1994 , three $\mathrm{Nb}-1 \mathrm{Zr}$ samples were irradiated by $800-\mathrm{MeV}$ protons at the Los Alamos Meson Physics Facility (LAMPF) to test the change in material properties (i.e. strength, ductility, etc.) due to proton (and neutron) irradiation. A total of three samples were fabricated into an irradiation assembly, each 0.020 in. thick, as shown in Figure 3. Also included in the assembly was an aluminum ( $99.9408 \%$ purity) sample used to measure the distribution of the proton beam. All samples were marked to maintain proper orientation following the irradiation.
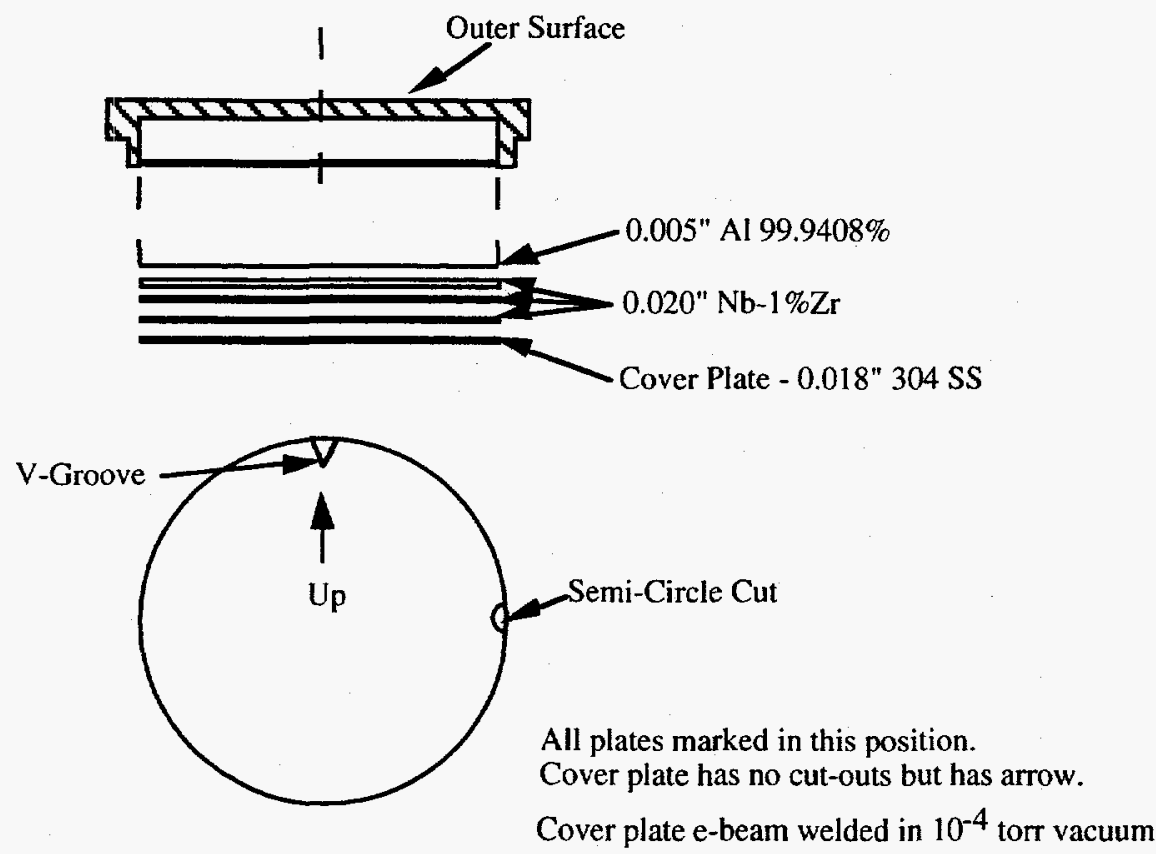

Figure 3. Irradiation assembly.

Initially, two coated samples were going to be included in the irradiation experiment to test the ability of coatings to maintain their integrity under proton irradiation. Samples were sent to the ALON Company for coating with alumina. Although experienced in using this type of coating on stainless steels, ALON was unable to successfully coat the Nb-1Zr. ALON attributed this failure to incorrect temperatures during the coating application and stated that a substantial experimental development effort would be required to be able to perform a successful coating. Hence, the alumina coating was abandoned for the irradiation experiment.

Earlier, small samples of $\mathrm{Nb}-1 \mathrm{Zr}$ were coated with $\mathrm{MoSi}_{2}$, and some simple oxidation experiments were performed. Although the $\mathrm{MoSi}_{2}$ was ineffective in reducing the oxidation rates of the $\mathrm{Nb}-1 \mathrm{Zr}$ at high temperatures, an attempt was made to obtain an $\mathrm{MoSi}_{2}$-coated 
sample for the proton irradiation in order to obtain some information on coating degradation. Unfortunately, attempts to coat the larger samples required also failed due to the mismatch in thermal expansion coefficient between the sample and the coating. Again it was determined that development of a successful coating technique was impractical under the time restraints. Thus, no coated samples were included. After proton irradiation, the sample assembly was moved to hot cell for post-irradiation examination.

\subsection{Molybdenum, Tantalum, and Tungsten}

Brown and Cost [12] investigated the tensile properties of Ta and Mo after $800-\mathrm{MeV}$ proton irradiation at LAMPF. Ta specimens retained significant ductility (approximately $17 \%$ ) after proton fluence of $1.5 \times 10^{20} \mathrm{p} / \mathrm{cm}^{2}$, while several Mo specimens broke at less than $0.2 \%$ strain after proton fluence of $1.3 \times 10^{19} \mathrm{p} / \mathrm{cm}^{2}$. Thus, all the candidate refractory metals of Mo, Ta, and $\mathrm{W}$ have their own problems as containment materials for the $\mathrm{ABC} / \mathrm{ATW}$. Mo becomes too brittle after low-fluence proton irradiation. Ta has an unacceptably high thermal neutron absorption cross section (21.3 barns) and poor oxidation resistance. W also has a high thermal neutron absorption cross section (19.2 barns) and low ductility.

Another possible way to alleviate the materials problem for the lead target is the use of coolant to lower the window temperature. By reducing the maximum operating temperature at the proton window, more candidate materials would be available.

\section{Lead-Bismuth Eutectic Target}

\subsection{Materials Compatibility}

As an alternative to a liquid-lead target for the LANL ABC/ATW systems, a liquid-leadbismuth eutectic target was investigated.

In the literature, several researchers used thermal convection loop tests to investigate materials compatibility with lead-bismuth eutectuic. During the 1950s, Cygan [13, 14] performed $\mathrm{Pb}-\mathrm{Bi}$ eutectic thermal convection and pumped loop tests for several steel alloys; the results of the tests are shown in Table 3. Main points of the results were the following: (1) when a steel surface is not completely deoxidized, impurities $\left(\mathrm{Bi}_{2} \mathrm{O}_{3}, \mathrm{~Pb}_{3} \mathrm{O}_{4}\right)$ rather that corrosion products appeared to be the major factors resulting in the stoppage of passage; (2) a possible method of metal purification might be the use of a magnetic trap; (3) lowcarbon steel appeared to be a useful container for the eutectic up to $454^{\circ} \mathrm{C}$; and (4) there was no advantage in using 410 or 446 stainless steel up to $454^{\circ} \mathrm{C}$. Weeks [15] reviewed the 
early work of metallurgical studies on $\mathrm{Bi}$ and $\mathrm{Bi}$ alloys for reactor fuels or coolants. Later in the 1960s, Romano, Klumet, and Gurinsky [16] investigated container materials for $\mathrm{Pb}$, $\mathrm{Pb}-\mathrm{Bi}$ eutectic, and $\mathrm{Pb}-\mathrm{Mg}$ eutectic in thermal convection loops operating at temperatures up to $650^{\circ} \mathrm{C}$ and at average flow velocity of $1.5 \mathrm{~cm} / \mathrm{s}$. The results are tabulated in Table 4 . A loop made of Croloy $1-1 / 4$ (Fe-0.15C-1.25Cr-0.5Mo) with a temperature range of 200 $400^{\circ} \mathrm{C}$ ran for 10,000 hours without signs of corrosion. A similar uninhibited loop with a temperature range of $300-450^{\circ} \mathrm{C}$ at Chalk River Nuclear Laboratories plugged in 1,700 hours [17]. At $650^{\circ} \mathrm{C}$ severe corrosion was observed in less than 100 hours.

Table 3. Results of lead-bismuth eutectic thermal convection loop test [13].

\begin{tabular}{|c|c|c|c|c|}
\hline Container Material & $\begin{array}{l}\text { Velocity } \\
(\mathrm{cm} / \mathrm{s})\end{array}$ & $\begin{array}{c}\text { Hot Leg } \\
\text { Temperature }\left({ }^{\circ} \mathrm{C}\right)\end{array}$ & $\Delta \mathrm{T}\left({ }^{\circ} \mathrm{C}\right)$ & $\begin{array}{c}\text { Time for } \\
\text { Stoppage }(\mathrm{hr})\end{array}$ \\
\hline $\begin{array}{l}1015 \text { steel } \\
1 / 4^{\prime \prime} \mathrm{D} \\
1 / 8^{\prime \prime} \text { wall }\end{array}$ & 3.3 & 454 & 277 & 450 \\
\hline $\begin{array}{l}410 \text { stainless steel } \\
1 / 2^{\prime \prime} \text { ID } \\
1 / 16^{\prime \prime} \text { wall }\end{array}$ & 8.8 & 454 & 500 & 1600 \\
\hline $\begin{array}{l}446 \text { stainless steel } \\
5 / 8^{\prime \prime} \text { ID } \\
1 / 16^{\prime \prime} \text { wall }\end{array}$ & 7.0 & 454 & $266-277$ & 2000 \\
\hline $\begin{array}{l}1015 \text { steel } \\
1 / 4^{\prime \prime} \text { ID } \\
1 / 8^{\prime \prime} \text { wall }\end{array}$ & 4.5 & $\overline{454}$ & 288 & 220 \\
\hline $\begin{array}{l}410 \text { stainless steel } \\
1 / 2^{\prime \prime} \text { ID } \\
1 / 16^{\prime \prime} \text { wall }\end{array}$ & 3.6 & 454 & 277 & 950 \\
\hline $\begin{array}{l}446 \text { stainless steel } \\
5 / 8^{\prime \prime} \text { ID } \\
1 / 16^{\prime \prime} \text { wall }\end{array}$ & 6.1 & 454 & $222-277$ & 1030 \\
\hline
\end{tabular}

Table 4. Corrosion of steels in lead-bismuth eutectic [16].

\begin{tabular}{||l|l||}
\hline $\begin{array}{l}\text { Severe corrosion } \\
<1,000 \mathrm{hr}\end{array}$ & Croloy 1-1/4 (uninhibited) $\left(500-625^{\circ} \mathrm{C}\right)$ \\
\hline $\begin{array}{l}\text { Severe corrosion } \\
1,000-5,000 \text { hours }\end{array}$ & Croloy 1-1/4 (uninhibited) $\left(400-550^{\circ} \mathrm{C}\right)$ \\
\hline $\begin{array}{l}\text { No corrosion } \\
\text { Up to } 5,000 \mathrm{hr}\end{array}$ & $\begin{array}{l}\text { Croloy } 1-1 / 4 \text { (Ti added) }\left(350-650^{\circ} \mathrm{C}\right) \\
\text { Carbon steel (Ti or } \mathrm{Zr} \text { added) }\left(200-500^{\circ} \mathrm{C}, 450-600^{\circ} \mathrm{C} \text {, and } 500-\right. \\
\left.650^{\circ} \mathrm{C}\right)\end{array}$ \\
\hline $\begin{array}{l}\text { No corrosion } \\
\text { Up to } 10,000 \text { hours }\end{array}$ & $\begin{array}{l}\text { Croloy } 1-1 / 4 \text { (uninhibited) }\left(200-400^{\circ} \mathrm{C}\right) \\
\text { Croloy } 1-1 / 4\left(\mathrm{Zr} \text { added) }\left(500-650^{\circ} \mathrm{C}\right)\right. \\
\text { Carbon steel (Zr added) }\left(500-650^{\circ} \mathrm{C}\right)\end{array}$ \\
\hline
\end{tabular}

Inhibitors are very effective in reducing the corrosion of steel by forming, for example, carbide and nitride films on the surface. Zirconium is perhaps the most effective inhibitor of 
low-alloy steels [16], and it also has a lower thermal neutron cross section than titanium. The required concentration of titanium is slightly more difficult to maintain than that of zirconium. Zirconium nitride is the major component of the protective film at the steel/bismuth interface in a zirconium-inhibited system [18]. Magnesium or calcium normally are added to the liquid metal in concentrations below $1,000 \mathrm{ppm}$ as an oxygengetter. Magnesium concentrations above $1,000 \mathrm{ppm}$ in $\mathrm{Bi}$ loops appear detrimental because of suppression of zirconium solubility and possible intermetallic compound formation. In $\mathrm{Pb}-\mathrm{Bi}$ eutectic at $450^{\circ} \mathrm{C}, 350 \mathrm{ppm}$ of $\mathrm{Mg}$ appears to be the upper desirable limit [19]. In $\mathrm{Bi}$, about 250-ppm Mg and 250-ppm $\mathrm{Zr}$ were the optimum inhibitor concentrations [20]. It was necessary to add inhibitors during the loop operation $[16,21]$.

If inhibitors are used during the $\mathrm{ABC} / \mathrm{ATW}$ operation, a variety of spallation products built up by the interaction of high-energy protons with target material will react with inhibitors in the $\mathrm{Pb}-\mathrm{Bi}$ eutectic. These reactions may reduce the beneficial effect of inhibitors. More research on the interaction between the spallation products and the inhibitors is required.

Weeks, Rosenblatt, and Wilson $[22,23]$ tabulated the solubilities of several metals in $\mathrm{Pb}$-Bi eutectic, as shown in Table 5. Both chromium and nickel are more soluble than iron. Thus, for stainless steels, selective leaching of these components takes place with increasing $\mathrm{Cr}$ and $\mathrm{Ni}$ concentration. In $\mathrm{Pb}-\mathrm{Bi}$ eutectic [19] and $\mathrm{Bi}[16,24]$, the corrosion increases with the chromium content in steel: Carbon steels are the most corrosion-resistant; low alloy steels $(<2-1 / 4 \% \mathrm{Cr})$ are moderately corrosion-resistant; and high $\mathrm{Cr}$ steels $(>2-$ $1 / 4 \% \mathrm{Cr})$ are subject to gross attack $[16,24-26]$. Nitrided Croloy $2-1 / 4$ (Fe-0.15C-2.2Cr$1.0 \mathrm{Mo}$ ) was more corrosion-resistant than the as-received material [16], and the corrosion rate decreased with increasing nitrogen content $(0.01 \%-1 \%)$ of Croloy $2-1 / 4$ [26]. The high solubility of nickel excludes the use of austenitic stainless steel or nickel-base alloys as a containment material for $\mathrm{Pb}-\mathrm{Bi}$ eutectic.

Table 5. Solubilities of several metals in lead-bismuth eutectic [22, 23].

\begin{tabular}{|l|c|c|c|}
\hline Metal & Temperature $\left({ }^{\circ} \mathrm{C}\right)$ & Solubility $(\mathrm{ppm})$ & Reference \\
\hline \hline $\mathrm{Cu}$ & 500 & 7200 & 18 \\
\hline $\mathrm{Fe}$ & 500 & 2.3 & 18 \\
\hline $\mathrm{Cr}$ & 500 & 11.0 & 19 \\
\hline $\mathrm{Ni}$ & 500 & 25000 & 19 \\
\hline $\mathrm{Co}$ & 500 & 50.3 & 19 \\
\hline $\mathrm{Ti}$ & 600 & 300 & 18 \\
\hline $\mathrm{Zr}$ & 600 & 329 & 18 \\
\hline
\end{tabular}


The corrosion is commonly velocity-dependent, the rate-controlling step being the migration of dissolved iron or chromium through the boundary layer of liquid adjacent to the steel surface [22]. However, Weeks and Klamut [24] noticed that the velocity in itself did not appear to accelerate corrosion in a liquid-bismuth thermal convection loop test. Very little difference in corrosion rate was observed between thermal convection loops in which the flow velocity was about $1.5 \mathrm{~cm} / \mathrm{s}$ and pumped loops in which flow velocity was as high as $424 \mathrm{~cm} / \mathrm{s}$. However, the circulating system was sensitive to disturbances in the flow. Severe attack had been encountered in hot portions of loops in which there were changes in the direction of fluid flow.

\subsection{Candidate Materials for Pb-Bi Eutectic Target}

The highest temperatures in the LANL ABC/ATW liquid-lead-bismuth eutectic target, where protons impinge on the window, are estimated to be $530-650^{\circ} \mathrm{C}$ depending on the flow design. Even though carbon steels showed strong corrosion resistance in $\mathrm{Pb}-\mathrm{Bi}$ eutectic and in $\mathrm{Bi}$, their upper limit for use under continuous load usually is $370^{\circ} \mathrm{C}$. At elevated temperatures of $370^{\circ}-650^{\circ} \mathrm{C}$, iron-based heat-resistant alloys are usually considered. The properties of carbon and low-alloy steels change considerably over this temperature range. Considering that there is not much stress exerted on the container material, all the low-alloy steels seem to have enough strength; however, a complete stress analysis in the target region of the ABC/ATW system will be necessary to verify this.

Brown, Wechsler, and Tschalaer [27] studied the tensile properties of pure iron, 2$1 / 4 \mathrm{Cr}-1 \mathrm{Mo}$ steel, and $\mathrm{HT}-9$ after $800-\mathrm{MeV}$ proton irradiation at LAMPF. The samples were sealed inside capsules containing lead-bismuth eutectic and were proton-irradiated to two fluences, 4.8 and $54 \times 10^{23} \mathrm{p} / \mathrm{m}^{2}$. After high-fluence irradiation, both $2-1 / 4 \mathrm{Cr}-1 \mathrm{Mo}$ steel and HT-9 showed more than $10 \%$ ductility and yield strength of more than $600 \mathrm{MPa}$, while pure iron showed approximately $8 \%$ ductility and yield strength of $200 \mathrm{MPa}$. The two ironbase alloys also showed much smaller fractional changes in yield strength and ultimate tensile strength than the pure iron. The $2-1 / 4 \mathrm{Cr}-1 \mathrm{Mo}$ steel showed a little higher ductility and lower strength than HT-9. Both HT-9 and 2-1/4Cr-1Mo steels appear adequate for a proton beam window in contact with $\mathrm{Pb}-\mathrm{Bi}$ eutectic.

Based on the literature survey, the materials discussed below are selected as candidate container materials for the $\mathrm{Pb}-\mathrm{Bi}$ eutectic targets for the ABC/ATW system. The general tendency for these materials is that the lower the chromium content in the alloy, the higher corrosion resistance to the eutectic and the less strength, and vice versa. 


\subsubsection{2-1/4Cr-1Mo Steel}

The corrosion tests of Croloy 2-1/4 (Fe-2.2Cr-1Mo) in bismuth [16, 22, 24, 26] and of Croloy $1-1 / 4$ (Fe-1.25Cr-0.5Mo) in lead-bismuth eutectic $[16,21]$ have been reported by many researchers. The $2-1 / 4 \mathrm{Cr}-1 \mathrm{Mo}$ steel also has been used extensively throughout the power industry as the final superheater for oil-fired power stations operating at a main steam temperature of $540^{\circ} \mathrm{C}$ and midwall temperature of $580^{\circ} \mathrm{C}$ [28]. It has too low of a creep strength to be accepted generally as a final-stage superheater material for use with a steam temperature of $565^{\circ} \mathrm{C}$. It is ductile and readily fabricated and can be welded using electrodes of the same composition. It is available commercially in a variety of product forms. The elevated behavior of this steel has been studied more thoroughly than that of any other Cr-Mo steels [29]. Additional creep strength and oxidation resistance can be provided by increasing the $\mathrm{Cr}$ content. Alloys containing 5\%,9\%, and $12 \% \mathrm{Cr}$ have been used for nuclear industry superheaters, usually where the oxidation or creep strength of 2$1 / 4 \mathrm{Cr}-1 \mathrm{Mo}$ is not adequate.

\subsubsection{Modified 9Cr-1Mo Steel}

$9 \mathrm{Cr}-1 \mathrm{Mo}$ steel has been used for superheaters in both coal- and oil-fired stations. The vanadium-niobium-modified $9 \mathrm{Cr}-1 \mathrm{Mo}$ (Fe-0.1C-9Cr-1Mo-0.5Mn-0.4Si-0.2V-0.08Nb$<0.2 \mathrm{Ni}$ ) was developed by Oak Ridge National Laboratory and has greater strength than $2-1 / 4 \mathrm{Cr}-1 \mathrm{Mo}$ at elevated temperatures. The modified $9 \mathrm{Cr}-1 \mathrm{Mo}$ steel, previously covered in Code Case 1943 of the ASME Boiler Code, now is covered in the regular code. The alloy is designated ASTM grade 91 and is specified in ASTM standards for boiler tubes (ASTM A 213), forgings (ASTM A336), seamless pipe (ASTM A335), and forged and bored pipe (ASTM A369). The corrosion behavior of this alloy in $\mathrm{Pb}-\mathrm{Bi}$ eutectic is not known.

\subsection{3 $12 \mathrm{Cr}-1 \mathrm{Mo}$ Steel}

This steel has the highest creep strength and oxidation resistance of the Cr-Mo steels. It does, however, present some problems in fabrication, and it requires special precautions. The application of this steel in the U.S. has been hindered by its relatively difficult welding characteristics [29]. It is not a listed material in the ASME Boiler and Pressure Vessel Code.

HT-9 (Fe-12Cr-1Mo-0.2C-0.4Si-0.5Ni-0.5Mn-0.3V-0.5W-0.02P-0.01S) is a brand name of Sandvik of Sweden. HT-9 is widely used for boiler tubing in Europe, but it is not an ASME Code material and therefore is not available commercially in the U.S. at present. 


\section{Other Low-Melting-Point Alloys}

It is desirable, from a materials standpoint, to reduce the operating temperatures of the target region of the $\mathrm{ABC} / \mathrm{ATW}$, and this can be achieved by employing less-poloniumproducing and less-corrosive low-melting-point alloy targets. Lead-magnesium eutectic $\left(98 \mathrm{~Pb}-2 \mathrm{Mg}\right.$ ) has a melting point of $248.7^{\circ} \mathrm{C}$. The addition of $2 \mathrm{wt} \% \mathrm{Mg}$ to $\mathrm{Pb}$ increased the severity of corrosion of Croloy 2-1/4, and uninhibited $\mathrm{Pb}-\mathrm{Mg}$ eutectic cannot be contained in Croloy 2-1/4 [16]. Zr inhibitor was added to the eutectic but would not go into solution, which indicated low solubility. The corrosion experiment results of this alloy are shown in Table 6. Lead-tin eutectic $(38.1 \mathrm{~Pb}-61.9 \mathrm{Sn})$ has a melting point of $183^{\circ} \mathrm{C}$. The neutronic analysis for the ABC/ATW system showed that this alloy does not produce any serious Po or toxic daughter material, so it is considered as a coolant material to reduce the temperature of the proton window for the liquid-lead target. No data have been found on corrosion behavior of this alloy in $\mathrm{Pb}-\mathrm{Bi}$ eutectic.

Table 6. Corrosion of Croloy 2-1/4 in lead-magnesium eutectic [25].

\begin{tabular}{|c|c|}
\hline \hline Hours to Severe Corrosion & Temperature Range $\left({ }^{\circ} \mathrm{C}\right)$ \\
\hline \hline$<1000$ & $488-550$ \\
\hline $1000-5000$ & $510-550$ \\
\hline
\end{tabular}

Alloys with melting points below the boiling point of water are known as fusible alloys. These are used for binding plugs in automatic sprinkler systems, low-temperature boiler plugs, solder for pewter and other soft metals, for tube bending, and for casting patterns for many ornamental articles and toys. Their compositions and melting points are shown in Table 7. Unfortunately, all of these alloys contain Po-producing bismuth, and it appears that there are not many advantages to using them.

Table 7. Alloys with melting points below $100^{\circ} \mathrm{C}$.

\begin{tabular}{|c|c|c|c|c|c|}
\hline Alloy & \multicolumn{4}{|c|}{ Composition } & Melting point $\left({ }^{\circ} \mathrm{C}\right)$ \\
\hline & $\overline{\mathrm{Pb}}$ & $\overline{\mathrm{Bi}}$ & Sn & $\mathrm{Cd}$ & \\
\hline Original Newton's alloy & $\overline{31.25}$ & 50 & 18.75 & 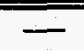 & 92 \\
\hline Newton's metal & - & 50 & 25 & 25 & 95 \\
\hline Wood's metal & 25 & 50 & 12.5 & 12.5 & 70 \\
\hline D'Arcet's alloy & 25 & 50 & 25 & - & 93 \\
\hline Lichtenberg's alloy & 30 & 50 & 20 & - & 92 \\
\hline Malotte's metal & 20 & 46 & 34 & $=$ & 95 \\
\hline
\end{tabular}




\section{Conclusions}

For the lead target, only refractory alloys of $\mathrm{Nb}, \mathrm{Mo}, \mathrm{Ta}$, and $\mathrm{W}$ are worth consideration because of its high operating temperature. Each of these materials has its own disadvantages: $\mathrm{Nb}$ and $\mathrm{Ta}$ are easily oxidized; Mo becomes too brittle after proton irradiation; Ta and $\mathrm{W}$ have high-thermal-neutron-absorption cross sections; and $\mathrm{W}$ is very difficult to fabricate. Based on the assumption that all the oxidation phenomena results in thickness loss from the surface, thickness loss of $\mathrm{Nb}-1 \mathrm{Zr}$ in various environments were calculated. The results showed that uncoated $\mathrm{Nb}-1 \mathrm{Zr}$ may be used for one year at $900^{\circ} \mathrm{C}$ at $\mathrm{P}_{\mathrm{O}_{2}}=1 \times 10^{-6}$ torr, but the same material may not be used in argon with 5-ppm oxygen. At $\mathrm{P}_{\mathrm{O}_{2}}=1 \times 10^{-7}$ torr at $900^{\circ} \mathrm{C}$, the thickness loss due to oxidation for $\mathrm{Nb}-1 \mathrm{Zr}$ does not seem to be a problem. Further study of the internal oxidation and hydrogen embrittlement of $\mathrm{Nb}$ $1 \mathrm{Zr}$ is required. For the lead-bismuth eutectic target, three candidate container materials were selected based on a literature survey. These are Croloy $2-1 / 4$, modified $9 \mathrm{Cr}-1 \mathrm{Mo}$, and HT-9. These materials may be used only if the lead-bismuth is thoroughly de-oxidized and treated with $\mathrm{Zr}$ or $\mathrm{Mg}$ inhibitor. The interaction between the spallation products and the inhibitors needs to be studied. The corrosion resistance of these Cr-Mo steels to the eutectic will be improved by nitriding.

\section{Acknowledgments}

The authors would like to express thanks to Walter Sommer, Robert S. Reid, Steve Wender, and Keith Woloshun from LANL for their contributions to this work. 


\section{References}

1. J.V. Cathcart and W.D. Manly, "The Mass Transfer Properties of Various Metals and Alloys in Liquid Lead," Corrosion 12, 43-47 (1956).

2. J.J. Park and J.J. Buksa, "Selection of Flowing Liquid Lead Target Structural Materials for Accelerator Driven Transmutation Applications," in Int. Conf. on Accelerator Driven Transmutation Technologies and Applications, E.D. Arthur, Ed. (AIP, New York, 1995), pp. 512-518.

3. J.R. DiStefano and J.W. Hendricks, "Oxidation Rates of Niobium and Tantalum Alloys at Low Pressures," Oxidation of Metals 41, 365-376 (1994).

4. E.J. Delgrosso, R.C. Krutenat, C.E. Carlson, and J.S. Carta, "The Oxidation Characteristics of Niobium-1Zirconium Alloy," J. Less-Common Metals 5, 57-77 (1963).

5. F. Fairbrother, The Chemistry of Niobium and Tantalum (Elsevier, New York, 1967), pp. 25-26.

6. T.F. Lion, "Low-Pressure Oxidation of Cb-1Zr Alloy," J. Vac. Sci. Technol. 8, VM48-VM58 (1971).

7. C.A. Beard, Los Alamos National Laboratory, personal communication, 1994.

8. J.R. Stephens, "Role of $\mathrm{Hf}$ and $\mathrm{Zr}$ in the Hydrogen Embrittlement of $\mathrm{Ta}$ and $\mathrm{Cb}$ alloys," in Hydrogen in Metals (American Society for Metals, Metals Park, Ohio, 1974), pp. 383-392.

9. R.A. Perkins and G.H. Meier, "The Oxidation Behavior and Protection of Niobium," J. of Metals 42, 17-21 (1990).

10. A. Mueller, G. Weng, and R.A. Rapp, "Deposition and Cyclic Oxidation Behavior of a Protective (Mo, W)(Si, Ge) $)_{2}$ Coating on Nb-Base Alloys," J. Electrochem. Soc. 139, 1266-1275 (1992).

11. C.M. Packer, Oxidation of High-Temperature Intermetallics, T. Grobstein and J. Doychak, Eds. (The Minerals, Metals, and Minerals Society, Warrendale, Pennsylvania, 1988), pp. 235-244.

12. R.D. Brown and J.R. Cost, "Mechanical Properties of $800-\mathrm{MeV}$ Proton-Irradiated Metals, in Effects of Radiation on Materials," American Society for Testing and Materials report STP 782 (1982), pp. 917-926.

13. R. Cygan, "Circulation of Lead-Bismuth Eutectic at Intermediate Temperatures," North American Aviation, Inc. report NAA-SR-253 (1953).

14. R. Cygan, "Lead-Bismuth Eutectic Thermal Convection Loop," North American Aviation, Inc. report NAA-SR-1060 (1954). 
15. J.R. Weeks, "Metallurgical Studies on Liquid Bismuth and Bismuth Alloys for Reactor Fuels or Coolants" in Progress in Nuclear Energy Ser. 4, Technology and Engineering, Vol. 1, R. Hurst and S. McLain, Eds. (Pergamon Press, Headington Hill Hall, Oxford, United Kingdom, 1956), pp. 378-408.

16. A.J. Romano, C.J. Klumet, and D.H. Gurinsky, "The Investigation of Container Materials for $\mathrm{Bi}$ and $\mathrm{Pb}$ Alloys, Part I. Thermal Convection Loops," Brookhaven National Laboratory report BNL-811 (T-313), (1963).

17. B.C. Stonehill, "Note on Lead-Bismuth Thermal Convection Loop No. 2," Chalk River Nuclear Laboratories report FSD/ING-64 (1966).

18. J.A. James and J. Trotman, "Corrosion of Steels in Liquid Bismuth and Lead," J. Iron and Steel Inst. 194, 319-323 (1960).

19. G.R. Dimmick, "A review of Lead/Bismuth Technology Relevant to the ING Primary Circuit," Chalk River Nuclear Laboratories report FSD/ING-136 (1968).

20. B.R.T. Frost et al., "Liquid Metal Fuel Technology" in Progress in Nuclear Energy Ser. 4, Technology, Engineering and Safety, Vol. 2, R. Hurst, R.N. Lyon, and C.M. Nicholls, Eds. (Pergamon Press, Headington Hill Hall, Oxford, United Kingdom, 1960), pp. 378-408.

21. R.I. Hodge, R.B. Turner, and J.L. Platten, "Corrosion by Liquid Metals," J.E. Draley and J.R. Weeks, Eds. (Plenum Press, New York, 1970), pp. 283-302.

22. J.R. Weeks, "Lead, Bismuth, "Tin and Their Alloys as Nuclear Coolants," Nuclear Engineering and Design 15, 363-372 (1971).

23. G. Rosenblatt and J. R. Wilson, "The Solubility of Several Transition Metals in Liquid Lead-Bismuth Eutectic" in Corrosion by Liquid Metals, J. E. Draley and J. R. Weeks, Eds. (Plenum Press, New York, 1970), pp. 469-477.

24. J.R. Weeks and C.J. Klamut, "Reactions Between Steel Surfaces and Zirconium in Liquid Bismuth," Nuclear Science and Engineering 8, 133-147 (1960).

25. W.E. Berry, Corrosion in Nuclear Applications (John Wiley and Sons, Inc., New York, 1971), p. 316.

26. G.W. Horsley and J.T. Maslery, "The Corrosion of $2-1 / 4 \% \mathrm{Cr}-1 \%$ Mo Steel by Liquid Bismuth," J. of the Iron and Steel Inst. 189, 139-148 (1958).

27. R.D. Brown, M.S. Wechsler, and C. Tschalaer, "Tensile Properties of Several 800 MeV Proton-Irradiated BCC Metals and Alloys" in Effects of Radiation on Material Properties: 13th International Symposium, Part, American Society for Testing and Materials report STP-95 (1987), pp. 131-140.

28. L.M. Wyatt, Ferritic Steels for Fast Reactor Steam Generators, Vol. 1, S.F. Pugh and E.A. Little, Eds. (British Nuclear Energy Society, 1978), pp. 27-34.

29. E.J. Vineberg, P.J. Grobner, and V.A. Biss, "Ferritic Steels for High-Temperature Applications," A.K. Khare, Ed. (American Society for Metals, Metals Park, Ohio, 1983), pp. 305-318. 